\title{
STRATEGI PENGEMBANGAN KAMPUNG NELAYAN PASAR BENGKULU SEBAGAI KAWASAN WISATA KOTA BENGKULU
}

\author{
MeiffaHerfianti \\ meiffaherfianti@gmail.com \\ Yesi Indian Ariska \\ yesiindian@yahoo.com \\ Program Studi Manajemen Fakultas Ekonomi dan Bisnis \\ Universitas Dehasen Bengkulu
}

\begin{abstract}
The pattern of development in the city of Bengkulu is directed at building tourism and its development. This is because most of the city of Bengkulu is in the coastal region of the Indonesian Ocean. The potential of tourist areas in the city of Bengkulu is very large, especially for the development of tourism based on sea and fisheries. The Bengkulu City Government has established coastal area development programs, one of which is in Bengkulu Market Fisheries Village. Facilities and infrastructure supporting coastal tourism have been sought by the Bengkulu City government such as the construction of tourist area entrances, shelters, parking lots and other supporting facilities. Other support is to mobilize the community to sell Bengkulu special culinary and other sea culinary, so that the development of fisherman villages as tourist areas can be achieved.
\end{abstract}

Keywords: tourism, coastal, fisheries.

\section{PENDAHULUAN}

\section{Latar Belakang}

Sektor Pariwisata merupakan salah satu sektor yang sangat strategis bagi perekonomian suatu daerah. Terutama dalam meningkatkan Pendapatan Masyarakat, Pendapatan Asli Daerah dan Devisa Negara. Pariwisata dapat memberikan banyak manfaat sosial, ekonomi bahkan penunjang pembangunan dilingkungan hidup, selain itu pariwisata juga kerap dijadikan langkah awal yang dilakukan untuk memajukan perekonomian suatu Negara. Di Indonesia sector pariwisata mendapatkan perhatian khusus dari pemerintah pusat dan daerah. SetiapProvinsi di Indonesia saling berlomba-lomba untuk menyajikan dan mengembangkan sector pariwisata guna menarik wisatawan untuk datang ke objek wisata termasuk di Provinsi Bengkulu.

Dalam Rencana Pembangunan Jangka Menengah (RPJMD) Propinsi Bengkulu tahun 2010-2015, sektor pariwisata tetap menjadi prioritas pembangunan daerah. Yaitu diarahkan untuk mengembangkan potensi wisata secara terpadu dan terintegrasi, 
membangun sarana dan prasarana kepariwisataan, meningkatkan promosi wisata, meningkatkan pengelolaan dan pelestarian keanekaragaman seni dan budaya, meningkatkan peran serta masyarakat, lembaga adat dalam pengembangan dan pelestarian budaya lokal karena dinilai sebagai sektor strategis dan dianggap mampu untuk membangun kemandirian daerah sebagai pendorong pertumbuhan sektor-sektor lain.

Pola dasar pembangunan Kota Bengkulu menggariskan bahwa pembangunan kepariwisaatan diarahkan pada pengembangan pariwisata sebagai sektor andalan pertumbuhan ekonomi, terutama di daerah pemukiman kampung nelayan. Potensi yang dimiliki kawasan pantai Kota Bengkulu telah disadari oleh pemerintah daerah dan kemudian dijadikan salah satu kebijakan yang strategis oleh Gubernur Bengkulu, yaitu menjadikan kawasan pantai tersebut sebagai kawasan wisata. Pengembangan wisata kawasan pantai Kota Bengkulu ini diharapkan mampu meningkatkan Pendapatan Asli Daerah (PAD) dan kesejahteraan masyarakat Kota Bengkulu dan sekitarnya, (Santoso, 2008).

Pemerintah daerah telah menetapkan program-program pembangunan dikawasan pesisir dengan menempuh kebijakan mengenai pengembangan wilayah melalui pendekatan penataan ruang. Salah satu programnya berada di Kelurahan Pasar Bengkulu. Keberadaan perkampungan nelayan di Kelurahan Pasar Bengkulu, yakni lokasi studi yang diusulkan memiliki pengaruh yang besar terhadap peningkatan potensi wisata. Sektor kepariwisataan di Kelurahan Pasar Bengkulu kedudukannya sangat strategis. Tinjauan tersebut dinilai dari segi astronomis, geografis, sosial ekonomi, kultural historis dan pola perkampungan. Berbatasan dengan Samudra Indonesia dan Sungai Serut memungkinkan masyarakat Kelurahan Pasar Bengkulu dapat untuk mengembangkan usaha perikanan yang sangat berharga dan bernilai ekonomi yang tinggi. Dikawasan ini pula akan dikembangkan kawasan wisata sejarah dan budaya, (Santoso, 2008).

Potensi lainnya adalah dibukanya jalan lingkar luar yang menghubungkan Sungai Hitam (perbatasan Kota dengan kabupaten Bengkulu Tengah) hingga ke Pantai Panjang Bengkulu, merupakan akses masuk wisatawan sehingga diharapkan kawasan ini menjadi menarik untuk dikunjungi.

Keberadaan Sungai Serut (sumber daya lokal yang belum ter-optimalkan) memiliki potensi untuk dikembangkan sebagai atraksi wisata. Terdapatnya situs sejarah Benteng YORK dan Tugu Pahlawan sebagai bukti sejarah perjuangan masyarakat Bengkulu melawan Belanda. Dan telah dilakukan penelitiannya oleh tim Penelitian Pusat Arkeologi Nasional Kementrian Pendidikan dan Kebudayaan pada tahun 2013. Sehingga menjadi potensi wisata sejarah di kampung nelayan Pasar Bengkulu

\section{METODE PENELITIAN}

Penelitian ini bersifat deskriptif kualitatif. Bersifat deskriptif yaitu suatu metode penelitian yang berusaha mendeskripsikan atau menggambarkan/melukiskan fenomena atau hubungan antar fenomena yang diteliti dengan sistematis, factual 
dan akurat (Natsir, 1998). Penelitian deskriptif digunakan bertujuan agar peneliti dapat menggambarkan dengan lebih baik sifat-sifat yang diketahui keberadaannya serta relevan dengan variable-variabel yang diteliti. Pendekatan dalam penelitian ini merupakan pendekatan kualitatif untuk menggambarkan tanggapan responden terhadap obyek berdasarkan kuesioner yang diberikan. Penelitian Kualitatif adalah suatu pendekatan yang juga disebut pendekatan investigasi karena biasanya peneliti mengumpulkan data dengan cara bertatap muka langsung dan berinteraksi dengan orang-orang ditempat penelitian (McMillan dan Schumacher, 2003).

Metode analisis yang digunakan adalah menggunakan analisis SWOT. Semua elemen dalam SWOT akan dijaring melalui jawaban responden terhadap pertanyaan yang diajukan. Analisis SWOT digunakan untuk mengidentifikasi dan merumuskan suatu strategi. Analisis SWOT didasarkan pada logika untuk memaksimalkan Kekuatan (Strength) dan Peluang (Opportunitiess), namun secara bersamaan dapat meminimalkan Kelemahan (Weakness) dan Ancaman (Treath).

\section{HASIL PENELITIAN}

Guna menentukan strategi pengembangan Kampung Nelayan Pasar Bengkulu sebagai kawasan wisata Kota Bengkulu perlu dilakukan identifikasi faktor internal yang terdiri dari faktor kekuatan dan kelemahan serta faktor eksternal yang terdiri dari faktor peluang dan ancaman terhadap aspek-aspek penelitian.

\section{Identifikasi Faktor Internal}

Dalam usaha Kampung Nelayan Pasar Bengkulu sebagai kawasan wisata Kota Bengkulu perlu dilakukan penilaian terhadap kekuatan maupun kelemahan yang dimiliki yang terakumulasi dalam faktor internal (internal factors).

Tabel 1

Faktor Internal PengembanganKampungNelayan

\begin{tabular}{|c|c|c|}
\hline \multicolumn{3}{|c|}{ Faktor Internal } \\
\hline & Kekuatan (Strengths) & Kelemahan (Weaknesses) \\
\hline $\begin{array}{l}3 . \\
4 . \\
5 . \\
6 . \\
7 . \\
8 .\end{array}$ & $\begin{array}{l}\text { Atraksi panorama alam } \\
\text { Dekatdenganpusatkota/per } \\
\text { tokoan } \\
\text { Dekatdenganobjekwisatalai } \\
\text { nnya } \\
\text { Adanyafasilitaspendukung } \\
\text { Keramahtamahanpenduduk } \\
\text { sekitar } \\
\text { Stabilitaskeamanan yang } \\
\text { memadai } \\
\text { Lokasi yang strategis } \\
\text { Aksesibilitas yang mudah }\end{array}$ & $\begin{array}{l}\text { 1. Kurangnya kegiatan promosi } \\
\text { 2. Belum menjadi tujuan utama } \\
\text { wisata } \\
\text { 3. Terbatasnya sarana dan } \\
\text { prasarana penunjang } \\
\text { 4. Terbatasnya SDM } \\
\text { pengelolawisata } \\
\text { 5. Masih kurangnya investor } \\
\text { 6. Retribusi dan parkir liar } \\
\text { 7. Belum adanya manajemen } \\
\text { pengelolaan }\end{array}$ \\
\hline
\end{tabular}




\section{Identifikasi Faktor Eksternal}

Selain faktor kekuatan dan kelemahan, dalam usaha pengembangan Kampung Nelayan Pasar Bengkulu sebagai kawasan wisata Kota Bengkulu juga ada faktor-faktor eksternal yang merupakan peluang dan ancaman yang sangat berpengaruh terhadap strategi pengembangan Kampung Nelayan Pasar Bengkulu sebagai kawasan wisata Kota Bengkulu.

Tabel 2

Faktor Internal Pengembangan Kampung Nelayan

\begin{tabular}{|c|c|}
\hline \multicolumn{2}{|c|}{ FaktorEksternal } \\
\hline Peluang (Opportunities) & Ancaman (Threatment) \\
\hline $\begin{array}{l}\text { 1. Adanya even-even } \\
\text { tahunan yang diadakan } \\
\text { di lokasi wisata } \\
\text { 2. Dukungan warga } \\
\text { setempat } \\
\text { 3. Peluang adanya industri } \\
\text { kreatif } \\
\text { 4. Usaha kuliner laut } \\
\text { 5. Fasilitas promosi } \\
\text { tersedia } \\
\text { 6. Peluang pendapatan asli } \\
\text { daerah }\end{array}$ & $\begin{array}{l}\text { 1. Komitmen pemerintah } \\
\text { belum ada } \\
\text { 2. Belum adanya dukungan } \\
\text { perda } \\
\text { 3. Minat wisatawan untuk } \\
\text { berkunjung kedaerah lain } \\
\text { tinggi } \\
\text { 4. Adanya tujuan wisata } \\
\text { lainnya yang dianggap lebih } \\
\text { baik }\end{array}$ \\
\hline
\end{tabular}

Hasil analisis faktor internal (IFAS) dan analisis faktor eksternal (EFAS) diketahui total skor faktor internal dan faktor eksternal sebagaimana terangkum pada Tabel 3.

Tabel 3

Perbandingan Skor Faktor Internal dan Eksternal

\begin{tabular}{|c|c|c|c|}
\hline IFAS $_{\text {rata-rata }}$ & $\mathbf{2 , 9 5}$ & EFAS $_{\text {rata-rata }}$ & $\mathbf{3 , 3 0}$ \\
\hline $\begin{array}{c}\text { Total Skor } \\
\text { Kekuatan (S) }\end{array}$ & 3,20 & $\begin{array}{c}\text { Total Skor } \\
\text { peluang (O) }\end{array}$ & 3,00 \\
\hline $\begin{array}{c}\text { Total Skor } \\
\text { Kelemahan (W) }\end{array}$ & 2,70 & $\begin{array}{c}\text { Total Skor } \\
\text { Ancaman (T) }\end{array}$ & 3,60 \\
\hline S - W & $\mathbf{0 , 5 0}$ & $\mathbf{O}-\mathbf{T}$ & $\mathbf{( 0 , 6 0 )}$ \\
\hline
\end{tabular}

Berdasarkan tabel di atas maka nampak bahwa titik koordinat posisi Kampung Nelayan Pasar Bengkulu pada titik-titik sumbu kekuatan 2,95 dan sumbu peluang 3,30. Untuk lebih jelasnya dapat dilihat dalam diagram cartesius sebagaimana berikut 


\section{Gambar 1}

\section{Diagram SWOT Pengembangan Kampung Nelayan Sebagai Kawasan Wisata Kota Bengkulu}

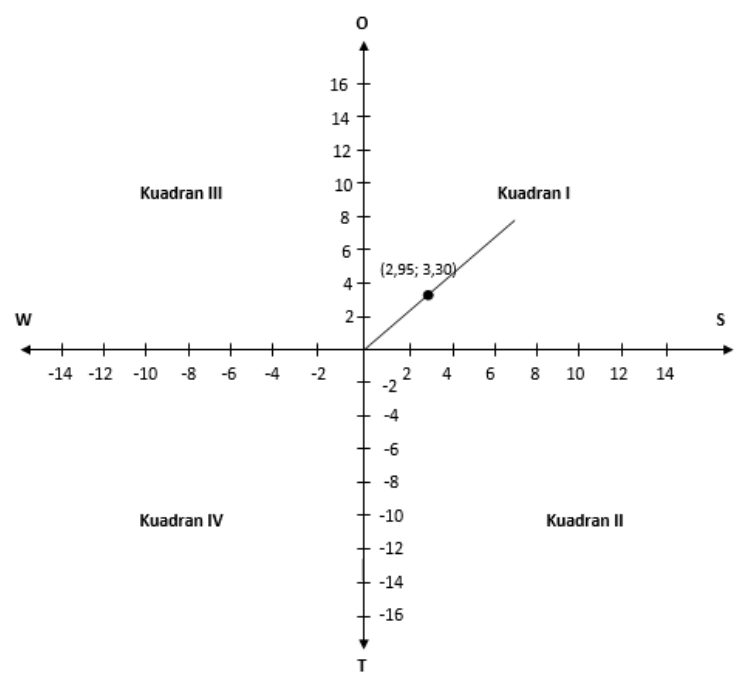

Jika dilihat dari Gambar 1, posisi strategi pengembangan Kampung Nelayan Pasar Bengkulu sebagai kawasan wisata Kota Bengkulu berada pada Kuadran I. Pada kuadran ini Kampung Nelayan Pasar Bengkulu menghadapi kondisi yang menguntungkan karena dapat memanfaatkan kekuatan yang bersumber dari internal untuk menghadapi lingkungan eksternal. Menghadapi kenyataan seperti ini, strategi yang semestinya dilakukan untuk pengembangan Kampung Nelayan Pasar Bengkulu sebagaimana ditunjukkan pada Tabel 4.

Tabel 4

Matriks Strategi Pengembangan Wisata Kampung Nelayan

\begin{tabular}{|c|c|c|}
\hline & Kelcuatan (Screngths) & Kelenahan (Weabresses) \\
\hline Elsternal Faltor & 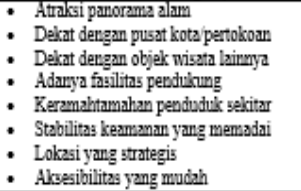 & 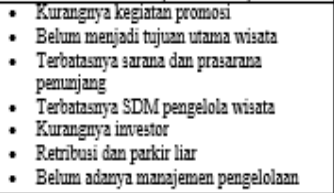 \\
\hline Peluaug (Opportuving) & S-0 Strategy & W-OStrategy \\
\hline 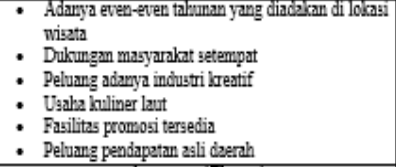 & $\begin{array}{l}\text { - Nembangun infiastrultur wizata } \\
\text { - Nengelola kavasan wigata dengan } \\
\text { baik sehingga memberi koutribusi } \\
\text { pada peningkatan PAD }\end{array}$ & $\begin{array}{l}\text { - Promosi wisata pada sazt even-even } \\
\text { tertentu baik di dalam maupun di luar } \\
\text { daerah terhadap Kampung Nelayan } \\
\text { - Nemberi peluang kepada inveator untuk } \\
\text { masuk dengan perizinan yang mudah }\end{array}$ \\
\hline Ancaman (Threass) & S-T Strategy & W-I Strategy \\
\hline $\begin{array}{l}\text { - Komitmen pemerintah daerah belum ada } \\
\text { - Belum adanya duhungan peraturan daerah } \\
\text { - Ninat wisatawan untuk berhmjumg ke daerah lain } \\
\text { tinggi } \\
\text { - Adarya tujuan wisata lairnya yang dianggap lebih } \\
\text { baik }\end{array}$ & 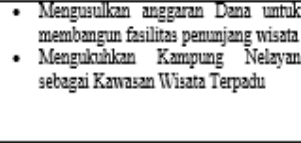 & $\begin{array}{l}\text { - Bekerjasama dengan pibak ketiga dan } \\
\text { dunia industri yang memiliki komitmen } \\
\text { dalam pengembangun visata } \\
\text { - Mengadakan even-even tertentu di lokasi } \\
\text { wisata Kampung Nelaym tidak terbatas } \\
\text { hanya pada even tahuman gaja }\end{array}$ \\
\hline
\end{tabular}


Berdasarkan matriks strategi pengembangan Kampung Nelayan Pasar Bengkulu sebagai kawasan wisata di Kota Bengkulu yang didasarkan pada pertimbangan faktor internal (kekuatan dan kelemahan) dan faktor eksternal (peluang dan ancaman), dapat diformulasikan strategi pengembangan antara lain sebagai berikut:

\section{Strategi S-0}

a) Membangun infrastruktur wisata yang memadai

b) Mengelola kawasan wisata dengan baik yang memberi kontribusi pada peningkatan PAD

\section{Strategi S-T}

a) Mengusulkan anggaran dana untuk membangun fasilitas penunjang wisata

b) Mengukuhkan lokasi wisata sebagai kawasatan wisata terpadu

\section{Strategi W-0}

a) Promosi wisata pada even-even tertentu di dalam dan di luar daerah

b) Memberi peluang kepada investor untuk berinvestasi dengan mudah

\section{Strategi W-T}

a) Kerjasama lintas sektor dan pihak pengembang

b) Mengadakan even-even di lokasi wisata secara rutin

\section{KESIMPULAN DAN SARAN}

\section{Kesimpulan}

Dari hasil penelitian dan pembahasan beberapa kesimpulan yang dapat diambil adalah sebagai berikut: Pertama, Pengembangan Kampung Nelayan Pasar Bengkulu sebagai kawasan wisata Kota Bengkulu tidak dapat dilakukan oleh pemerintah daerah saja. Upaya ini harus didukung oleh semua elemen masyarakat Kota Bengkulu. Kedua, Upaya promosi perlu dilakukan melalui even daerah dan even nasional untuk memperkenalkan objek wisata Kampung Nelayan Pasar Bengkulu. Ketiga, Dukungan sumberdaya dan sumber dana untuk pengembangan kawasan Kampung Nelayan Pasar Bengkulu harus dilakukan secara bertahap dan berkelanjutan. 


\section{DAFTAR PUSTAKA}

Abdullah Alfarabi. Diaksesdari ml. scribd. Com / doc / 36920346 / Analisis swot - lfas - efas

Arison. (2011,Maret). Diakses dari http://arison .blogspot.com/2008/02/pengertian -pariwisata.html.

BadanPusatStatistik Kota Bengkulu, 2013. Bengkulu dalamAngka.

Dinas Kebudayaan dan Pariwisata Provinsi Bengkulu dan Fakultas Ekonomi dan Bisnis Universitas Bengkulu. 2014. Pendataan Dan Analisa Kunjungan Wisatawan Ke Provinsi Bengkulu.

Ml, Jhingan. 2010 .Perencanaan Ekonomi Pembangunan. yogyakarta. Rajawali Pers.

Nur Indriantoro dan Bambang Supomo, 1999. Metodelogi Penelitian Bisnis, Yogyakarta, BPFE Yogyakarta.

Peraturan Daerah Provinsi Bengkulu Nomor 3 Tahun 2014. TentangPerubahanatasPeraturan Daerah nomor 4 tahun 2011 tentangRencana Pembangunan JangkaMenengah Daerah (RPJMD) ProvinsiBengkulu tahun 2010-2015. PemerintahProvinsi Bengkulu

Pitana, Ade danDiarta, I Ketut Surya. 2009. PengantarIlmuPariwisata. CV. Andi Offset Yogyakarta.

PitanadanGayatri. 2005. SosiologiPariwisata. Yogyakarta: Andi.

Rangkuti, Freddy. 2009. Analisis SWOT Teknik Membedah Kasus Bisnis. Jakarta: Gramedia.

Santoso, Urip. 2008. www.journal.com, Bengkulu menujukotapariwisata.

Sipayung, Helti Martini. 2012. Catatan akhir tahun-jalan berliku mendongkrak jumlah wisatawan. Bengkulu.

Suhartoyo. 2009. Belajar menuangkan pikiran. Di aksesdari<file:///G:/Jembatan\%20serut\%20(bhn\%priview\%202).ht $\mathrm{m}$

Undang-undang no. 10 (2009), kepariwisataan.

Yoeti, Oka A. 2000. Ekowisata pariwisata berwawasan lingkungan hidup. Jakarta. P.T. Pertja 